INTERNATIONAL JOURNAL FOR

HISTORY, CULTURE AND MODERNITY

www.history-culture-modernity.org

Published by: Uopen Journals

Copyright: () The Author(s).

Content is licensed under a Creative Commons Attribution 4.0 International Licence

eISSN: 2213-0624

\title{
References to Iconic Landscapes in the Debate Surrounding the Founding of Finland's National Parks, circa I880-I9I0
}

Juho Niemelä and Esa Ruuskanen

HCM 7: 741-764

DOI: $10.18352 / \mathrm{hcm} .579$

\begin{abstract}
This article reviews the formation of the idea of national parks in Finland between the I880s and I9IOs. It argues that both the term and the concept of national park evolved in a long-lasting deliberative process between competing definitions. The main actors in this process were geographers, forestry scientists and NGOs devoted to popular education and the promotion of tourism. As a result of the debates, iconic landscapes and species were located in Finnish nature inside the wholly artificial boundaries of the national parks. Eventually, both the science and tourism poles of the decades-long debate were incorporated into the plans and visions for Finland's national parks in the early twentieth century. The national park debate between the I880s and I9Ios focused mainly on landscapes, land formations and vegetation zones, and not so much on the wildlife or indeed the people who lived inside these areas.
\end{abstract}

Keywords: environmental history, environmental values, Finland, Lapland, national parks, nature conservation

\section{Introduction}

In 1938, Finland finally established its first national parks in the fells of Pallas-Yllästunturi and Pyhätunturi in Lapland; in the Heinäsaaret Islands off the north-east coast of Petsamo; and on Stora Träskö Island 
off the Cape of Porkkala in the Gulf of Finland. It had taken nearly sixty years of deliberation for these national parks to see the light of day.

In this article, we argue that the multifaceted development and formation of the national park concept in the Finnish context between I 880 and I9IO was the result of a long process involving competing definitions. The main actors in these deliberations were botanists, geographers, forestry scientists and NGOs devoted to popular education and the promotion of tourism. The main forums for these debates were scientific societies and their periodicals, parliamentary committees, and the press. We do not, however, approach the issue purely from a rhetorical angle, but also analyse how the idea of a national park became embedded in the material environment. As a result of the deliberations, iconic landscapes were located within the wholly artificial boundaries of national parks. It is therefore equally important to consider why certain areas and species were excluded from the conservation and preservation plans tied up with the management of national parks.

The aim of this study is to understand how the national park concept, a term originally adopted from abroad, gradually established itself as an idea in twentieth-century Finnish conservation and preservation circles. We examine national parks by looking at the pragmatic use of language by those parties arguing for conservation and preservation. As the debates progressed, ideas were used that could be clearly linked to pressing contemporary real-world conservation concerns, such as the loss of forests, unique scenic places and so-called natural monuments.

Existing studies on the history of Finnish national parks ${ }^{1}$ are mostly in Finnish, and they do not approach the subject from the same perspective as our study. That is, they do not focus on the long-term process of deliberation that was involved. Globally, the history of national parks has been studied from various angles, from Roderick Nash's account of changing attitudes towards wilderness as a national concept ${ }^{2}$ to Bernhard Gissibl's approach of contemplating national parks as an expression of 'cosmopolitics' ${ }^{3}$ National park histories are usually a mixture of national and environmental history, but they may also feature the transnational transfer of knowledge, and the adoption of ideas across borders, though in a less fundamental way than portrayed by Gissibl. ${ }^{4}$

The essential debate over the founding of national parks in Finland began in the I880s following a proposal by the explorer Adolf Erik 
Nordenskiöld, and it was over by the I9IOS as the more pressing concerns of World War I (I9I4-I8) and the Finnish Civil War (27 January to I5 May I9I8) took over. The debate resurfaced in the early I920s, but the ideas at this point largely rested on the plans and ideas that had previously been outlined in the period preceding the wars. In the I920s and early I930s, the discussion was more about practical legal, organizational and land ownership details than any major new theoretical angles. For this reason, our study focuses on the late-nineteenth and early-twentieth-century debate about creating a national park system in Finland. Although it remained a top-down process, and was never a popular social or political movement, ${ }^{5}$ the national park debate was clearly one manifestation of the spirit of the age, which was to create institutions and symbols that would enhance the country's image of itself as a modern, civilized nation. This ongoing nation-building process used education to define good citizenship and articulate desired social futures, with a certain notion about progress.

Before we proceed, some background information on Finnish history is in order. Following Sweden's defeat in the war against Russia in I 809, the country became the autonomous Grand Duchy of Finland, and remained so until the Russian Revolution (I9I7). This meant that although it was now part of the Russian Empire, the country had its own senate, local officials, legislation, currency, and so on. Swedish and, after I863, Finnish were its official languages. The decades spanning the I880s and the I9IOs witnessed significant social and political upheavals. In Finland, economic liberalization and the civic activities of various new organizations gained momentum from the I860s onwards and began to have a fundamental effect on the ways in which the surrounding world was perceived. The pace of industrialization in Finland may seem slow when compared to other countries in Europe, but the forest industry grew in the late nineteenth century, and this affected the way people viewed the 'exploitation' of their woodlands. The idea of a distinct Finnish identity evolved in parallel with Finnish as a national language, which was seen to be equal, if not superior, to Swedish. Nevertheless, Swedish retained its dominant position as the administrative and scientific language of the country until the turn of the century. The growing nationalism was focused on culture, turning people's thoughts to language, ethnicity, history and a Finnish identity, as distinct from either Russian or Swedish. It also played a part, as we 
shall see, in the way artists and park enthusiasts alike sought to frame discussions about the natural environment in national romantic terms.

Modernization is a key concept to describe the developments in latenineteenth and early-twentieth-century Finland. It is, however, a complicated term, since it covers the social and cultural realms as well as the urban and rural spheres. The shared experience of 'modernization' is open to various interpretations. One aspect was a shift from a rigid system of representation by the traditional estates to a more civic, classbased society, in which there was greater room for individual liberty, the economy became more liberalized and there was more freedom of movement for workers - which, in turn, caused further industrialization. Another aspect of modernization was that citizens had the chance to organize themselves into civic groups which articulated positive visions of nationalism and societal progress. Debates about national parks also relied on this trend to form civic associations, as the discussions they provoked proved to be an excellent vehicle for developing distinctive ideas about modernization, culture and memory.

Today, Finland's National Parks are very popular among both domestic and foreign tourists, attracting over three million visitors in 2017 alone. ${ }^{6}$ In the I880s, however, it was not apparent that the parks would be so successful in attracting attention and support.

\section{Adolf Erik Nordenskiöld's Proposal}

Baron Adolf Erik Nordenskiöld was a famous Swedish-speaking Finnish Arctic explorer who, in 1880, suggested that 'national parks' (Rikspark) be set up to represent key natural features of the Nordic region, so that they could be protected from human activities. By 'human activities' he meant the lowering of lakes, the draining of wetlands and the felling of forests. ${ }^{7}$ As he was an influential scientist, this proposal received quite a lot of publicity in both Finland and Sweden. His reasoning sprang from a conviction that scientific, technological and economic progress were causing an irreparable transformation of the 'landscape of our forefathers'. This needed not so much to be stopped as to be channelled in the right direction, since the transformation in his opinion could benefit society in many ways. His ideas on nature conservation were thus grounded in cultural ambitions rather 
than in any deep ecological concern. According to Nordenskiöld, the best examples of the nation's wild ancestral regions could be found in the extensive Crown lands in the north of Finland and Sweden. National parks could be established easily there as was no need to negotiate with private land owners. Within these national park areas, the exploitation of natural resources and the killing of animals (except those deemed 'harmful') would be prohibited. In Nordenskiöld's vision, 'in addition to fertile woodland and meadowland', the ideal national park would also feature 'tree-covered hills, lakes, heaths and bogs' so that 'the view would not become unbalanced'. ${ }^{8}$

Nordenskiöld's proposal did not specify or rule out certain kinds of landscapes for the national parks in Finland and Sweden. On the contrary, he argued that they should include a variety of geographical features, flora and fauna, excluding only the most harmful predators. His image of national parks was thus a naturalistic one, including rough and uninviting terrain as well as the picturesque. For Nordenskiöld, national parks were to be 'natural museums' showing what 'harsh conditions' the people's ancestors had been forced to overcome to evolve into the 'tough people of the North' ${ }^{9}$ In this respect, it was an utterly romantic view of what national parks could represent for a modernizing nation state. He did not seek to eliminate human impact on nature altogether, but to regulate it within a conserved area. In this sense, his proposal can be seen as a reaction to 'modernity', ${ }^{10}$ as it entailed a degree of loss (e.g. pristine forests) at the expense of advancement - even if his attitude to that loss was ambivalent, if not welcoming. The same contradiction between nature conservation and notions of progress can also be seen in Nordenskiöld's attitude to 'harmful' predators, which in his mind could be simply eliminated from the park. It was a utilitarian view of national parks; they were the product of a system of selection driven by humans, and the parks were important due to their cultural and educational resonance.

Nordenskiöld's initial proposals proved to be influential, serving as the basis for arguments and concepts which emerged later on regarding national parks. To begin with, the discussion was driven by a rather narrow scientific elite, taking place in learned societies and their journals, or in committees appointed by the senate of the Grand Duchy of Finland. Occasionally, the Finnish press would publish stories about the issue, but national parks were far from being front page news during the 
period in question. They were generally dwarfed by the more burning social and political questions of the time, such as the plight of leasehold farmers and the russification of Finland.

The question of national parks was debated by forest scientists who mostly wanted to reframe Nordenskiöld's original plans. Anton Gabriel Blomqvist, the director of the Forestry School of Evo and the founder of the Finnish Forest Association (Finska Forstföreningen), supported Nordenskiöld's proposal, but approached it from a more scientific standpoint. For Blomqvist, national parks were not only 'natural museums ... for the study of nature', for those 'who loved nature' and for recreation; they were also 'a sanctuary for indigenous plant and animal species'. He referred to ideas justifying the establishment of national parks that had already been presented by George Perkins Marsh in The Earth as Modified by Human Action (I864). ${ }^{\mathrm{II}}$ In addition, Blomqvist made Nordenskiöld's idea more concrete by specifying that each national park in Finland should be at least 3000 hectares. However, he disagreed with Blomqvist's idea that Crown lands should be used, since timber continued to be felled and land cleared there. Blomqvist saw Aavasaksa in Lapland as a suitable area for a park that might represent a typical northern landscape, while further south, he reasoned, a national park could be established somewhere near a railway station so that visitors could get there easily. ${ }^{12}$ As a result of the expedition by the Italian Giuseppe Acerbi to the fell in I799, and the romantic paintings depicting it, Aavasaksa had become a destination recognized among the European gentry as the best place to see the midnight sun. What is more, the fell could now be reached not only by boat via the River Torne, but also by road. By proposing Aavasaksa as a national park site, Blomqvist seems to have been taking aesthetic aspects into account as well as more scientific ambitions.

Blomqvist's plan aroused a mixture of both interest and suspicion among Finnish forest scientists. Some agreed with Nordenskiöld's and Blomqvist's ideas, while others judged the idea too costly to ever be realized. Chief Forester Adolf Wilhelm von Zweydberg, one of the earliest national park supporters in the early I88os, went one step further to realizing Blomqvist's plan by suggesting that Ähtäri or Keuruu in Central Finland might be ideal places for a southern national park, since both were near a train station. ${ }^{13}$

There was a pause in the debate about national parks until I 89I, when the topic was reopened by Ragnar Hult, an academic at the Department 
of Geography at the Imperial Alexander University in Finland. By stressing the importance of natural parks to Finnish culture, science and the economy, he returned to the central points of Nordenskiöld's and Blomqvist's plans. At the same time he emphasized the benefits that could be gained by establishing these 'laboratories of nature', as he called them. Natural parks fostered silvicultural aims, and they could act like outdoor research stations, providing botanists and foresters with a protected area where the 'coexistence of plant species', 'interaction of plants and the soil' and the 'water cycle' in a 'natural environment' could be observed. Although Hult saw the clear cultural relevance of the plans for national park, he clearly stressed their scientific and utilitarian value. Environmental protection was no longer the chief goal in these plans; unlike Nordenskiöld, Hult thought that there was actually 'too much wilderness area in Finland'. ${ }^{14}$ There were some conservationist elements in his proposal, but they were somewhat conflicted. Hult's plans bear resemblance to the conservation ideas of the Russian zoologist, Grigorii Aleksandrovich Kozhevnikov, who saw virgin natural environments as models of efficiency and productivity, which agriculturalists and forest scientists should strive to emulate. Kozhevnikov's ideas about the organization of 'protected areas' (zapovedniki), rested on the assumption that truly rational economic activity was impossible without prior scientific study of a virgin natural environment; protected areas should be left pristine so that they could then be observed by scientists. ${ }^{15}$ It is unclear as to whether Hult actually knew Kozhevnikov's writings, but the resemblance is noticeable.

Within a decade the arguments for founding national parks had thus veered towards a scientific bias. Nordenskiöld had argued that national parks, with their wild terrains representing the nation's uncivilized past, should be established for the Finnish people as much as for scientists and their research. For him, the untamed wilderness of the north represented iconic landscapes that would serve the educational purpose of reminding Finns of the hardships their ancestors had once had to endure. Blomqvist, too, centred his plans on Aavasaksa in Lapland, which was already an iconic, touristic showcase, but diverged slightly from Nordenskiöld's socio-historical objectives by emphasising the recreational aspects: natural parks should also be for those who 'loved nature'. Finally, Hult emphasized more than Blomqvist the scientific and economic utility of national parks, and placing those over national 
and aesthetic concerns. All of these arguments for establishing national parks would re-emerge in the I89os and I9oos.

\section{Breaking away from Plans for Scientific National Parks}

The debate on national parks would move away from scientific arguments only in the late I89os. It had been carried out among a small circle of scientists but there had been no concrete results; it seemed the plans of this educated elite were out of touch with the realities faced by farmers, who had to contend with frosts, flooding, animal pests and plant disease. Late nineteenth-century Finland was an agricultural economy, and for those making their living from the soil, nature had to be tamed and cultivated. By I897 not one single natural park had been established, nor had the subject ever been discussed in the Senate of Finland.

The debate was nevertheless revived in the late I 890 os by geographers Johan Peter Norrlin and Johan Evert Rosberg, the newspaperman and photographer I.K. Inha and the newly established Finnish Tourist Association (Suomen matkailijayhdistys). Norrlin's plan was first mooted at a meeting of Societas Pro Flora et Fauna Fennica, the oldest scientific society in Finland, and appeared in its journal in I 898. In many respects it was a synthesis of plans that had come before. Norrlin used the term 'nature reserve' (naturpark), which suggested what the latest ideas were about: the protection of certain areas from human activities that might alter the natural environment, and scientific research into virgin natural environments. By emphasizing the importance of nature reserves for forest science and silviculture, Norrlin seemed to be drawing the central ideas for his plan from Blomqvist and Hult. He can therefore be seen as a conservationist with a strong scientificutilitarian view. Norrlin, nevertheless, also proposed that national parks or nature reserves might be established by private landowners and run on a relatively tight budget. In that case, they would be quite small in size, and there could be many throughout the country. These protected areas would have cultural importance for locals and scientific value for those who sought to understand the natural world better. Larger national parks would cost more and be the responsibility of the state; consequently, Norrlin argued, they would take longer to establish. ${ }^{16}$

While Norrlin emphasized the scientific and silvicultural value of national parks as a social justification for their establishment, Rosberg 
approached the issue from a different angle. He started from the premise that national parks might serve both as a tourism resource and a means for highlighting the uniqueness of the Finnish landscape. Rosberg described how the national park system had evolved in the USA; then it was discussed in Finland by Nordenskiöld, Blomqvist and Hult. He pointed out that for designated areas to become 'real national parks', all 'forestry, agriculture and killing and imprisonment of animals' would have to be prohibited. Rosberg expressed concern about the fact that some of 'the most beautiful wildlife', especially some species of goose and whooper swan, had become endangered. This was the first time that the protection of animal species had specifically featured in the Finnish national park debate. Rosberg stated that 'future generations will deem us barbarians for having destroyed and damaged all that once made the Finnish landscape uniquely beautiful, unless we take immediate action to ensure that at least one strip of land is saved from the transformative forces of civilization.' Rosberg's ideal location for one such 'strip of land' was Kuusamo-Oulanka in north-eastern Finland, 'with its lofty fells and deep lakes in the Koillismaa region of Northern Ostrobothnia' ${ }^{17}$

Rosberg was therefore a conservationist in both idealistic and ethical terms. He seemed to be aware of developments in conservation in Central Europe and, in line with national romantic ideas, drew attention to aesthetic and ethical aspects rather than the purely scientific and silvicultural. As a person who had worked for over ten years as a secondary school teacher before becoming Professor of Geography at the Imperial Alexander University of Finland in 1902, he clearly considered popular educational goals to be of the utmost importance. For Rosberg, the tree-covered hills and boulder-strewn rapids of north-eastern Finland represented the most iconic of landscapes. People would come away from the park feeling morally edified and filled with a sense of their country's beauty.

I.K. Inha also highlighted the touristic potential of national parks, travelling across Finland to take photographs of traditional landscapes and ways of life that he thought were dying out as a result of modernization. Inha saw Imatrankoski, the rapids at Imatra in Southern Karelia and an iconic tourist attraction since the late eighteenth century, as an ideal place for one such national park. The surrounding area had already been given the status of 'nature reserve' by Tsar Nicholas I in I 842 , but according to Inha 'the banks of the rapids were so ravaged, that the charm visitors would hope to witness is not as it once was'. 
Imatrankoski had in his view been neglected and, as 'an ideal landscape attracting thousands of tourists', it deserved greater status as 'a large and beautiful national park'. By becoming a national park, Inha believed the 'ugly industrial and tourism facilities' that had already been built and planned could be stopped from encroaching on the area any further. He thought that the natural environment contained elements that were harmonious and purposeful, and urged the Finnish Senate to appoint a national park committee to advance the issue. ${ }^{18}$ Inha believed that Imatrankoski could be a kind of aesthetic showpiece for national parks, like Yellowstone in the USA. ${ }^{19}$ In this respect, nature fulfilled a nostalgic role and aestheticized as a powerful, free and long-lasting entity. Inha's position may have reflected the Finnish cultural elite's longing for political and intellectual freedom, as the russification of Finland gathered pace under Tsar Nicholas II. This conservative policy was aimed at both limiting the political autonomy of the Grand Duchy of Finland and redefining its cultural identity.

In I899, the Finnish Tourist Association (FTA) pointed out that the nature reserve of Punkaharju in Southern Savonia would make an ideal location for a large national park. Tsar Alexander I had made it a nature reserve in 1803 to protect the esker forests from further logging, and Punkaharju had since become an iconic tourist attraction. However, the association was indignant about the plans of a private company (Keuhkotautisten parantola Oy) to build a tuberculosis sanatorium in the area, as they believed the esker forests should be reserved exclusively for tourism. The association pointed out that Punkaharju was already valued as a de facto national park with its 'wonderful open lakes' that would 'compel the visitors to show devotion and admiration' for this 'sanctuary of nature.' Within such a landscape, a sanatorium would cause 'unfortunate confusion', they reasoned, ${ }^{20}$ adding that while they understood its importance, in this case, the location was wrongly chosen. 'Punkaharju is above all a tourism area,' the association stressed, 'but it is our national park, and it should remain so - undisturbed'. ${ }^{21}$ These thoughts were also shared by the Artists' Association of Finland. ${ }^{22}$

The national park visions of Rosberg, Inha and the FTA differed from the scientific justifications of the I880s and early I89os. They took a wholly aesthetic and ethical approach, suggesting sites that not only already had the status of being an iconic landscape for tourists, but also held a firm place in the imagery of romantic nationalism. Famous Finnish artists like Eero Järnefelt and Axel Gallén often painted 
expansive panoramas of coniferous forests, hills and lakes, conveying the unrestrained 'wild' power of the nation and the sacredness of untouched nature. Low-lying wetlands, for instance, which are equally common in Finland, were hardly ever depicted in these works of art. These national romantic illustrations also took pride of place in popular non-fiction books that aimed to promote a sense of Finnishness. ${ }^{23}$ In a sense this was a concerned cultural response to a modernization that coveted these landscapes as resource frontiers for forestry and mining. The Finnish wilderness of the north and east was born out of the sociocultural imaginations of the neo-romantic artists that depicted it, and the chief protagonists of the national park movement championed it. Although these landscapes were largely uninhabited by humans, they were nevertheless familiar. North-eastern Finland had provided good hunting grounds for centuries, of elk, roe deer and wild reindeer, for instance; the lakes and rivers offered good fishing, apart from serving as routes of communication. In Lapland, the reality was that this imagined wilderness had been inhabited for centuries already by the Saami people. Their traditional reindeer-herding areas and sacred monuments that had been important to their culture, were excluded from this national, romantic meaning-making process.

Blomqvist, von Zweydberg and Norrlin prioritized scientifically relevant forest areas, while Rosberg, Inha, and those who wished to promote tourism in Finland put distinctive scenery before everything else. For the latter, national parks were therefore showpieces of Finland's nature rather than natural research stations or pieces of an ancestral environment that needed preserving. The establishment of the FTA in I 887 had meant that tourism in Finland became increasingly organized, and the debate on national parks was caught up in these goals. National parks were now seen as a means of consolidating the Finnish national identity, and they had become more prominent than ever since Nordenskiöld's first proposal.

\section{From Conwentz's Ideas to the Return of Silvicultural Ambitions}

Originally Nordenskiöld and Blomqvist had determined that quite an extensive land area would be required for a national park, so that enough natural species could be represented. In Rosberg's, Inha's and 
the FTA's vision, the land area thought necessary for a national park had decreased substantially in size. By the I9oos this trend continued, with small primeval forest areas being suggested, and even a single boulder or tree being considered as a nationally valuable monument.

At a meeting of the Geographical Society of Finland in I905, Johan Axel Palmén, professor of zoology at the Imperial Alexander University explained how the ideas about a 'natural monument' (Naturdenkmal) adduced by the German botanist Hugo Conwentz could be adopted in Finland. Palmén had studied at the University of Heidelberg and was familiar with German conservation ideas. ${ }^{24}$ Conwentz had been asked to come up with a conservation plan for Prussia in $\mathrm{I} 898$ and in that plan, as well as in the reports that followed, he paid attention to the protection of singular features of nature, not to mention small and threatened forest areas. Conwentz drew his ideas from a mixture of scientific, cultural and recreational ambitions contained in the political-cultural concept of Heimat, which aimed to extend the idea of natural heritage preservation to building national and regional identities. ${ }^{25}$ German nature preservation ideas were gradually and partly adopted in many European countries, including the Netherlands, Russia, Sweden and Switzerland. ${ }^{26}$ In I904 in Sweden a bill was presented in Parliament by the botanist Karl Starbäck, in which he proposed the establishment of national parks and justified his ideas in Conwentz's terms by underlining the connection between regionalism and a reverence for nature. ${ }^{27}$

Palmén was well aware of the Swedish debate on founding national parks. He saw regionalism as a way to interest local inhabitants in conservation. Palmén also wished that those who had previously been working independently of each other might make common cause to further national park and nature conservation issues together. He saw the projected high costs of national parks and the difficulty of finding suitable areas that were large enough as the main obstacles to their establishment. Natural monuments, however, would be more affordable in every sense, and easier to realize. The establishment of natural monuments could be initiated, for example, by 'civic organizations or locals without need for the state's financial backing'. To begin with, these monuments could be organized by 'the Geographical Society of Finland until a separate organization including local branches could be established to take charge over the coordination task.' Good examples of natural monuments could be the odd rock formations of glacial 
erratics, or small patches of extant primeval forest areas that were now surrounded by fields. These were threatened by 'expanding agriculture and the thoughtlessness of humans.' Certain environmental concerns run through Palmén's writings, but, at the same time, he clearly valued modernization as essential to the well-being and wealth of the nation. ${ }^{28}$ Palmén also sketched out ideas for the protection of some animal species, drawing attention to the Saimaa ringed seal as an example of one species that needed to be saved from extinction, although he did not specify how. He also reasoned that large predators such as brown bears and wolves would inevitably disappear from Finland 'as a result of progress,' which was, however, not such a significant loss in his opinion. ${ }^{29}$

Palmén's plan turned out to be quite different from the original ideas of Nordenskiöld. It did not bear any real fruits until the I920s, when the legal status of natural monuments was included in the Nature Conservation Act (I923). German ideas on nature conservation thus influenced the final form of the act, but the chief arguments for actually founding national parks were the same as they had been for Nordenskiöld, Blomqvist, Hult, Norrlin, Rosberg and Inha. This became evident in 1905 when the leading Finnish scientific societies appointed a committee to promote the establishment of a national park.

On May 22, I905, representatives of seven leading scientific organizations were called together for a meeting by the Finnish Forest Association (FFA) to push things forward and reframe the plans for a national park, which had again ground to a halt. The FFA, the Finnish Geographical Society, the FTA and Societas pro Fauna et Flora Fennica, were complemented by the Geological Society of Finland, the Finnish Hunter's Association and the Geographical Association of Finland. The representatives of these organizations included prominent Finnish scientists of the time, such as Palmén, Fredrik Elfving (professor of botany), Theodor Homén (professor of applied physics), Wilhem Ramsay (professor of geology), Arthur Rindell (professor of agricultural chemistry), Johan Evert Rosberg (professor of geography) and Jakob Johannes Sederholm (director of the Geological Commission). ${ }^{30}$

This National Park Committee (NPC) reiterated the plans of Blomqvist and von Zweydberg to found two parks, one in the north and another in Central Finland. As Nordenskiöld had once done, the committee suggested that state-owned Crown lands would make the best areas for a national park as the land acquisition would cost less. 
Regionalism was certainly taken into account by the committee, but national identity and scientific ambitions came first. The sites suggested were once again Kuusamo-Oulanka in the northeast and KuruRuovesi in Central Finland, as previously suggested by Blomqvist, von Zweydberg and Rosberg. The new regions proposed for national parks were the tree-covered hills of Kivalo outside Kemi in Lapland and the Tolvajärvi esker forest in Karelia. ${ }^{31}$

In the end, the committee followed the Swedish example and published a questionnaire, ${ }^{32}$ formulated by Elfving, Palmén and Sederholm, in leading Finnish newspapers to get feedback from the countryside and gather reasonable proposals (within certain restrictions) from locals on their opinions about a site for a national park or nature reserve. From now on, the committee mostly used the preservationist term 'nature reserve' when referring to Nordenskiöld's plans. The committee looked for an area of approximately I0O-400 square kilometres, representing all the major kinds of Finnish terrain, on which they could obtain detailed information about waterways, forests and plant species. ${ }^{33}$ This was a very ambitious plan and partly explains why the questionnaire did not produce the results hoped for, in either of the two proposed areas. ${ }^{34}$ The NPC members themselves finally took charge of the task, though most of the fieldwork was conducted by the state's foresters, who also filled out the questionnaire. By 1907, the committee had decided on a shortlist of areas to be surveyed in more detail. This included Saariselkä and Pallas in Lapland, Kuusamo-Oulanka in the northeast and Tolvajärvi in Karelia. ${ }^{35}$

At roughly the same time, in I906, the Grand Duchy's Senate appointed a commission to determine where 'protected forest areas' (suojametsäalue) should be founded. The commission was established because a report on silviculture by the Board of Forestry had suggested that an area for preservation be marked out somewhere in the northern fell district. ${ }^{36}$ The resulting 'Protected Forest Areas Commission' (PFAC) began to conduct field investigations in the north, and this would turn out to have a considerable influence on the national park debate. 'Protected forest' was originally a German concept (Schutzwälder), which was understandable considering that most Finnish forest scientists had been trained at German universities or forestry schools. Many of them had also made field trips to the Royal Saxon Academy of Forestry in Tharandt, which had already become a model for Finnish 
forestry education in the $18505 .{ }^{37}$ On the one hand, protected forests were addressing environmental concerns over aesthetically and economically valuable natural environments; on the other, they represented the growing ambitions of nation states to reassert control over their resource frontiers. A 'frontier' in this context implied that these designated areas were on the periphery, and thus involved the projection of values onto a distant place. ${ }^{38}$

In Finland the idea of protected forests turned out somewhat differently than in Central Europe. Chief Forester Gustaf Emil Wichmann, surveyor Olli Pajari and professor of geography Johan Evert Rosberg were sent on behalf of the PFAC to Sweden and Norway to familiarize themselves with the protection of the Arctic and sub-Arctic conifer forest areas. The result was a report in I9IO expressing a concern over the vulnerability of forest resources in Lapland. Forests in the north, the report stated, should be 'carefully treasured' rather than overcut to prevent deforestation due to the growing demand for timber. It was the state's responsibility to limit the depletion of forest resources in Lapland, so that the forest might be conserved in what had become a very vulnerable environment. The report proposed that the area of protected forest should cover a fairly large 'expanse of fell' and include 'mountain birch zones and pinewoods', somewhere between the parishes of Muonio and Saariselkä. ${ }^{39}$ This was an area of traditional importance to the area's Saami inhabitants, but the report did not take this into account.

The PFAC suggested that a national park be established somewhere close to a protected forest area. It referred to the fact that nine national parks had been established in Sweden in I909, and that each of these represented a particular kind of terrain. Sweden had not tried to find one single area in which all kinds of Scandinavian terrain could be found, but had instead established a network of national parks extending the length of the country, even if most were in Swedish Lapland. Indeed, the PFAC also suggested that Pallas-Ounastunturi and PyhäLuostotunturi in Finnish Lapland would be the best place for Finland's first national parks. As Rosberg was one of the three involved in compiling the report, it is hardly any wonder that it also recommended that a national park be created around the Oulanka in the northeast to protect it from further logging and settlement; $4^{\circ}$ Rosberg had already suggested this area in I897. 
One of the reasons the PFAC recommended these three areas was because they partially matched those suggested by the NPC in I907. Pallastunturi was seen 'to represent typical northern fell and forestry at its best.' As for the Pyhätunturi fell, it was a unique place not only to 'carry out geological research', but because it afforded 'beautiful views of the mountain area.' Both areas were located quite close to a train station in Rovaniemi, opened only a year earlier, and from there it was only a short trip by boat to Pyhätunturi, and by road to Pallastunturi. The idea was that these national parks would benefit both scientists and tourists alike; ${ }^{41}$ a nature conservation model that could embrace both aesthetic-touristic aspects and scientific-utilitarian ends. The north looked more inviting as the state was the biggest landowner there. Somewhat ironically, increased modernization now made it easier to reach these areas via better transport networks; the same process threatened virgin forests, as the demand for raw materials grew. Trains not only transported people and ideas, but also timber, thereby making logging in the north finally profitable.

By referring to parts of Finnish Lapland as the 'wilderness', the PFAC effectively practised a form of colonialism which left the Saami out of the meaning-making process. The plan was based on an asymmetric perspective, in which Lapland was seen as some distant exotic place. The Saami, for instance, would be prevented from letting their reindeer graze in the national park areas. This was justified on grounds that "reindeer would destroy the native flora in a few years". ${ }^{42}$ The exclusion of reindeer herding would have effectively meant the exclusion of the Saami from their historic lands, as many of them relied on this traditional livelihood.

\section{Outcomes of the National Park Debate before Finnish Independence}

Even though this topic had been discussed since the I880s, the national park issue had still not been resolved by I9I0, and in the next few years, far more pressing issues pushed it into the background. In Finland, the I9I os were marked by the Great War, the collapse of the Russian empire and the Finnish Civil War and its aftermath. Another reason why this issue had been protracted for so long was that it had remained an elitist 
subject. It had failed to mobilize the general population to think about which areas should be treated as nationally important and worth protecting. As we saw, it was not until the late I930s that the first national parks were finally established in Finland, almost thirty years later than Sweden and twenty years later than Switzerland. But it was not the only country where the issue had taken decades to result in anything tangible. National parks were not established until I95 I in the UK, I962 in Norway, I963 in France, I970 in Germany, I974 in Denmark and Greenland, and I98I in Austria. This was because in each case, the national park issue was a complicated mix of concerns regarding education, conservation, regional and scientific policies, tourism and land ownership, all of which had to be reconciled before any concrete action could be taken.

The deliberations over founding national parks in Finland, nevertheless, mattered to the evolving public debate about the need for conservation and preservation. In that debate common goals for the protection of nature and/or specific animal species were defined. By the beginning of the twentieth century, the terms 'national park' and 'nature reserve' had become part of the political lexicon, even if by twenty-first-century standards they were often used inconsistently. Members of the Finnish Parliament, for example, referred to national parks while debating the prohibition of elk hunting in $1907 .{ }^{43}$ The Agrarian Party, which was not very pro-conservation, used the term rhetorically in pursuit of its bid to have the Hunting Act changed so that farmers could hunt in 'all areas except natural parks' ${ }^{44}$ At the very least, this shows that 'national park' as a place where hunting was forbidden was already a concept that MPs understood, even if parks had only been discussed on an abstract level. It was understood that national parks implied conservation of some kind, even if the debate was generally considered to be more about regulating human use rather than eliminating human impact altogether.

Between I880 and I9I4, the protected areas of special national importance had slowly taken shape, and the idea of a national park had become more exact. The geographical emphasis of these plans began by focusing on the north of the country. The state was the major landowner there, so it would be relatively simple to procure the land; but another reason was that in the eyes of the urban scientific elite, Lapland represented the last remaining extensive wilderness still untouched by forestry or large-scale human activity. Wilderness had evolved, up to a 
point, into a romanticized space with exclusive practices related to the traditional livelihood of the Saami, which had been only partly commercialized. The finest examples of the fells of Lapland were thus promoted as a nationally unique landscape, the protection of which was considered beneficial to both science and tourism. It was felt that a large, nationally significant conservation area should include fells or tree-covered hills with aesthetically stunning views over the wilds and lakes. In addition, the flora and rock strata needed to be scientifically valuable to botanists, forestry scientists, geographers and geologists alike. National parks would epitomize the cultural mastery of nature in new ways, underlining the human capacity to conserve a piece of it for future generations. In a sense, areas assigned to national parks were scientific frontiers to be fully explored as well as tourism frontiers that were ready for controlled commercialization of the landscape. At the same time, imposing landscapes were expected to arouse admiration and elevate the national spirit, in a similar way to new architectural monuments. ${ }^{45}$

The role of wildlife inside national parks remained somewhat nebulous though, perhaps due to the fact that zoologists had only a minor part in the national park debate. Another factor was that early animal protection movements in Finland focused more on the rights of domestic animals and the protection of small birds than other animals. There were some, like Blomqvist and Rosberg, who wished to protect every species of animal within the national park. Rosberg argued, for instance, that certain species of goose and the whooper swan were integral parts of Finland's natural environment and expressed concerns over their endangerment. Interestingly, from the I950s onwards, whooper swans did in fact become one of the most iconic birds in Finland, and it is still a species that tourists hope to see in national parks today. Nordenskiöld, meanwhile, wanted to protect all animal species except those he called 'harmful predators' such as wolves and bears. Forestry scientists, on the other hand, did not pay so much attention to animal species. Even reindeer were considered a harmful mammal, the herding of which they suggested should not be allowed within national park boundaries. This now seems quite curious, considering that since the I950s reindeer have perhaps been the most iconic animal species of Lapland and one which all national parks generally wish to include.

When these issues were discussed again after the interlude of World War I, the science versus tourism poles of the earlier debate re-emerged. 
Rolf Palmgren, the first Government Inspector for the Protection of Nature in the early I920s, justified the establishment of national parks along the same lines as Johan Evert Rosberg had done twenty years earlier. The key argument was that every civilized nation should conserve select pieces of its natural environment so that future generations could share in the same natural heritage ${ }^{46}$ Palmgren's successor, however, professor of botany Kaarlo Linkola took a more science-oriented approach, similar to that of Blomqvist and Hult decades earlier. ${ }^{47}$

So it was that the first Finnish national parks finally became established at Pallastunturi and Pyhätunturi in Lapland, following the proposals of the NPC and the PFAC. The Kuusamo-Oulanka region that had been much discussed earlier as the other possible location, eventually became Oulanka National Park in I956. The end result was a hybrid system that included characteristics that had been advocated by both the science and tourism parties throughout the decades-long discussions. It should be borne in mind that this debate had been kept up between the I 880 os and I9Ios by a few educated individuals. It never included the general public or popular organizations; it seems that their interests were more related to social reform and political freedom.

\section{Conclusion}

We have analyzed the debates over the founding of national parks in Finland that took place between the I880s and I9Ios. Although the first national parks were not established until the I930s, most of the main ideas had already been lain out in the early stages of the debate. The topic interested both people in scientific circles who wanted to protect the natural environment and those who wished to promote tourism and recognized that a national identity could be founded on natural features of the landscape. Nationality became embedded in the material world, while at the same time the material world became a tool in the young nation's new 'civilizing' mission. Consequently, national parks were justified in both scientific and sociocultural terms during the period in question, and the concept of a national park became more institutionalized. This had an effect, for instance, on parliamentary rhetoric with regard to conservation policies and also on the development of a new geography syllabus for elementary schools. 
Generally speaking, the science-oriented arguments for national parks were proposed by prominent forest scientists and natural geographers, who wished to promote the establishment of national parks for the benefit of applied research and silviculture. They saw forests as iconic landscapes for scientific-utilitarian reasons. National identity, although it was advertised in their plans, was not at the core of their reasoning. It was, however, at the core of the tourism-oriented arguments for national parks. The geographer Johan Evert Rosberg, the journalist and photographer I.K. Inha, and the FTA all saw national parks as a crucial tool for popular education and promoting tourism. For these conservationists, national parks were showpieces of Finland's natural environment, whose wilderness could be romanticized and commercialized up to a point through tourism. Picturesque vistas afforded from the brow of a tree-covered hill or a windswept fell over a wide expanse of forests and lakes, fast-flowing rapids and glacial outcrops were valued above all and framed as iconic landscapes. In these national park debates from the I880s to the I9IOs, evocations of wilderness, or places which were conceived as such, manifested to some extent the nation's own longing for freedom in the decades leading up to its independence.

Eventually, both the science and tourism poles of the decades-long debate were incorporated into the plans and visions for Finland's national parks in the early twentieth century. The crisp outlines of national parks in Pallastunturi and Pyhätunturi and the Oulanka River near the Russian border emerged out of the fog that had shrouded their precise location since I 880 (when a location in Lapland had first been suggested) and I 890 (when Koillismaa was first brought to the table). In the eyes of the upper middle classes in Southern Finland, these areas represented an ideal pristine wilderness, relatively untouched by human hands. There was room for both scientific research and views of stunning scenery in these locations, so both parties in the debate were accommodated. Moreover, the question of land ownership was relatively simple, as the state was the biggest landowner there. Finally, the plans relating to the establishment of Protected Forest Areas in Lapland reinforced arguments for the national parks being situated there. However, the indigenous Saami people were clearly not given a voice in these discussions; if they had, reindeer herding would certainly not have been prohibited in the proposed national park areas. The national park debate between the I880s and I9Ios focused mainly on landscapes, land formations and 
vegetation zones, and not so much on the wildlife or indeed the people who lived inside these areas. The issue was perhaps more about finding and outlining suitably iconic landscapes for a young nation state, than necessarily conserving all aspects of the natural environment.

\section{Notes}

I See Pekka Borg and Hannu Ormio, Perustiedot kansallispuistoista: Ihanteet ja käytäntö (Porvoo, I978); Timo Järvikoski, 'Luonnonsuojelu ennen ympäristönsuojelua: Katsaus suomalaisen luonnonsuojelun varhaiseen aatteelliseen ja osin toiminnalliseenkin kehitykseen', J. Jokisalo and K. Väyrynen (eds), Ympäristökysymysten yhteiskunnallisia ja eettisiä näkökulmia (Oulu, 1993), 5-32; Riikka Puhakka Kansallispuistot murroksessa: Tutkimus luonnonsuojelun ja matkailun tavoitteiden kohtaamisesta (Joensuu, 2007); Anto Leikola, 'Luonnonsuojelun tulo Suomeen', in H. Telkänranta (ed.), Laulujoutsenen perintö. Suomalaisen ympäristöliikkeen taival (Helsinki, 2008).

2 Roderick Nash, Wilderness and the American Mind (New Haven, 200I).

3 Bernhard Gissibl, 'National Parks as Cosmopolitics', in Christof Mauch and Libby Robin (eds), 'The Edges of Environmental History: Honouring Jane Carruthers', RCC Perspectives (2014), 47-52.

4 Luigi Piccioni, Il volto amato della Patria: Il primo movimento per la conservazione della natura in Italia, I880-1934 (Camerino, I999); Tom Mels, 'Nature, Home, and Scenery: The Official Spatialities of Swedish National Parks', Environment and Planning D: Society and Space, Volume 20 (2002), I35-54; Lionel Laslaz, Vanoise: 40 ans de parc national; Bilan et perspectives (Paris, 2004); John Sheail, Nature's Spectacle. The World's First National Parks and Protected Places (London, 2010); Claire Campbell (ed.), A Century of Parks Canada, I9I I-20I I (Calgary, 20I I); Patrik Kupper, 'Translating Yellowstone: Early European Natural Parks', in B. Gissibl, S. Höhler and P. Kupper (eds), Civilizing Nature: National Parks in Global Historical Perspective (New York 20I2), I23-39; Carolin Firouzeh Roeder, 'Slovenia's Triglav National Park: From Imperial Borderlands to National Ethnoscape', in B. Gissibl, S. Höhler and P. Kupper (eds), Civilizing Nature: National Parks in Global Historical Perspective (New York, 2012), 240-55; Kupper, Patrick, Creating Wilderness: A Transnational History of the Swiss National Park (New York, 20I4). 
5 Compare this to the emergence of various cooperative organizations, Finnish youth associations (nuorisoseurat), temperance movements and working-men's clubs in the late nineteenth and early twentieth centuries.

6 http://www.metsa.fi/web/en/visitationnumbers (accessed I5 May 20I8).

7 Adolf Erik Nordenskiöld, 'Förslag till inrättandet af Riksparker i de nordiska länderna', Finska forstföreningens meddelanden no. I (I88I), I I-I 5, at I 3 .

8 Ibid., I4-5.

9 Ibid., I3.

Io The term 'modernity' would not been used by either him or his contemporaries.

I I Editorial, 'Vore det skäl att i Finland förverkliga det af Friherre Adolf Nordenskiöld väckta förslag till inrättande af "Riksparker" i de nordiska länderna, och huru kunde detta i sådan händelse genomföras', Finska forstföreningens meddelanden no I (I884), I 55.

I2 Ibid., 156.

I3 Ibid., I56-6o.

I4 'Nationalpark i Finland', Geografiska Förening Tidskrift I89I, 267-74.

I5 Weiner, Douglas, Models of Nature: Ecology, Conservation and Cultural Revolution in Soviet Russia (Pittsburgh, 2000), I2-4.

I6 'Om Utvägar att i Finland åstadkomma naturparker', Meddelanden af Societas pro Fauna et Flora Fennica (I897-I898), I34, I37-9.

I7 Uleåborgsbladet (I 2 June I897).

I8 Uusi Suometar (9 September 1897).

I9 Nash, Wilderness, 83.

20 Uusi Suometar (22 November I899).

2I Uusi Suometar (7 December I899).

22 Uusi Suometar (2 I November I 899).

23 Ville Lukkarinen, 'Kansallisen maiseman vertauskuvallisuus ja ympäristön tila', in Ville Lukkarinen and Annika Waenerberg (eds), Suomi-kuvasta mielenmaisemaan: Kansallismaisemat I800-1900-luvun vaihteen maalaustaiteessa (Helsinki, 2004), 20-89.

24 'Luonnon muistomerkkien suojelemisesta', Luonnon ystävä: yleistajuinen luonnontieteellinen aika-kauslehti (June I905).

25 Thomas Lekan, Imagining the Nation in Nature: Landscape Preservation and German Identity, I885-1945 (Cambridge, MA, 2004), 5 I-4.

26 Kupper, Translating Yellowstone, I26.

27 Mels, Nature, Home, and Scenery, I38-40. 
28 'Luonnon muistomerkkien suojelemisesta'.

29 Ibid.

30 Uusi Suometar (20 August I903); Helsingin Sanomat (I I April I905); Helsingin Sanomat (I 2 May I905); Helsingin Sanomat (I7 May I905); Uusi Aura (25 May 1905).

3 I Uusi Aura (25 May I905).

32 More on Swedish National Park plans in Sheail, Nature's Spectacle, 99-IO0.

33 Helsingfors-Posten (I3 June I905); Hufvudstatdsbladet (I3 June I905); Uusi Suometar ( 44 June I905); Helsingin Sanomat ( 5 June I905); Åbo Tidning ( 5 June I905); Vaasa (I7 June I905); Tornion Lehti (8 July I905).

34 Uusi Suometar ( 6 September I905); Helsingin Sanomat (I6 September I905).

35 Nya Pressen (I4 April I906); Hufvudstadsbladet (I 5 April I906).

36 'Maamme pohjoisimpiin osiin järjestettävien suojelusalueitten eroittamista varten asetetulta komisionilta', Komiteanmietintö (I9Io. no. 7), I-2.

37 A.K. Cajander, 'Katsaus Evon metsäopiston vaiheisiin', in Suomen metsänhoitoyhdistyksen julkaisuja I908 (Helsinki, I908), 250-2.

38 Gordon M. Winder and Andreas Dix, 'Commercial Knowledge and Environmental Transformation', in Gordon M. Winder and Andreas Dix (eds), Trading Environments: Frontiers, Commercial Knowledge, and Environmental Transformation, I750-I990 (New York, 20I6), I 2.

39 'Maamme pohjoisimpiin osiin järjestettävien suojelusalueitten eroittamista varten asetetulta komisionilta', Komiteanmietintö (I9I0), 2-6, I I 7-8.

40 Ibid., I 2 I-2.

4I Ibid., 229-32.

42 Ibid., 23 I-2.

43 'Armollinen esitys n:o I5 koskeva muutettuja määräyksiä hirven metsästämisestä, Valtiopäivien istunto 3.5.1907', Valtiopäivien asiakirjat, 580 (Parliamentary Session, 2 May 1907, Parliamentary Records of the Finnish Parliament); Sosialidemokraatti (4 June I907); Lahti (6 June I907).

44 Kaleva (I5 January I907).

45 Other architectural monuments of the time were, for instance, the Bank of Finland (I883), the Athenaeum Art Museum ( I 887), the National Theatre (I902) and the National Museum (I9IO). These evolved into iconic buildings and became an important part of Finland's national identity. 
46 Rolf Palmgren, Naturskydd och kultur I (Helsinki, I920); Rolf Palmgren, Naturskydd och kultur II (Helsinki, I922).

47 Kaarlo Linkola, 'Suunnitelma luonnonsuojelualueiden erottamiseksi Pohjois-Suomen valtionmailla', Silva Fennica no. I (I926), I-44.

\section{About the Authors}

Juho Niemelä received his MA in Finnish and Scandinavian history at the University of Oulu in 20I5. His thesis focused on national park plans in Finland between the I880s and I920s. E-mail: juhnieme@ gmail.com

Esa Ruuskanen is a Senior Research Fellow and the person responsible for the minor in Environmental Humanities at the University of Oulu. His research interests lie in the environmental history of peatlands and the environmental history of Finland. E-mail: Esa.Ruuskanen@oulu.fi 